\title{
Da comunicação tele (J.L.Moreno) à informação de campo semântico (A. Meneghetti): diferentes olhares para a mesma informação em consultoria ${ }^{1}$
}

\author{
Carmen Ivanete D`Agostini Spanhol ${ }^{2}$
}

\begin{abstract}
Resumo: No presente trabalho tem-se por objetivo articular o conceito desenvolvido pela Teoria Psicodramática sobre a comunicação Tele (MORENO, 1974;1987) e ampliar o conhecimento para leitura e compreensão das informações através do Campo Semântico (MENEGHETTI, 1993; 2010; 2015) proposto pela Ontopsicologia. Trata-se de uma pesquisa que se dispõe a fazer um estudo teórico e apresentar uma clarificação para o tema da comunicação/ informação em consultoria. O ponto de partida é a abordagem de Moreno $(1974 ; 1987)$ sobre comunicação Tele e se completa na leitura das informações de campo semântico apresentado por Meneghetti $(1993 ; 2010 ; 2015)$. O texto propõe a compreensão, ilustrada à luz de fragmentos de um Case. Apresenta nas considerações finais, pontos relevantes do contraponto entre os autores e abre a possibilidade ao profissional, de chegar ao conhecimento das causas, através do conhecimento de Campo Semântico.

Palavras-chave: Informação. Comunicação. Tele. Campo semântico. Ontopsicologia.
\end{abstract}

From tele communication (J.L. Moreno) to semantic field information (A. Meneghetti): different looks for the same information in consulting ${ }^{3}$

In this work there's the objective of articulate the concept developed by Psychodramatic Theory on Tele Communication (Moreno, 1974;1987) and expand the knowledge for reading and comprehension of information through Semantic Field (MENEGHETTI, 1993; 2010 ; 2015) proposed by Ontopsychology. It's a research that proposes to make a theoretical study and present a clarification to the theme of communication/information in consulting. The starting point is Moreno's approach $(1974 ; 1987)$ on Tele Communication and it completes itself on the reading of Semantic Field information presented by Meneghetti $(1993 ; 2010 ; 2015)$. The paper proposes the comprehension, illustrated by fragments of a case. It presents, on final considerations, important points of the counterpoint between the authors and opens the possibility to the professional to reach the knowledge of causes, through the knowledge of Semantic Field.

Keywords: Information, Tele Communication, Semantic Field, Ontopsychology

De la comunicación tele (J.L. Moreno) a la información de campo semântico (A.

Meneghetti): diferentes miradas para la misma información en consultoría ${ }^{4}$

Resumen: En el presente trabajo se tiene por objetivo articular el concepto desarrollado por la Teoría Psicodramática sobre la comunicación Tele (MORENO, 1974; 1987) y ampliar el conocimiento para lectura y comprensión de las informaciones por medio del Campo Semántico (MENEGHETTI, 1993; 2010; 2015) propuesto por la Ontopsicología. Se trata de una investigación que se dispone a hacer un estudio teórico y presentar una aclaración

\footnotetext{
${ }^{1}$ Reelaboração, em 2018, das reflexões realizadas para elaboração de trabalho de conclusão do Curso de Formação Livre em Psicodrama, em 2006.

${ }^{2}$ Professora universitária, Consultora individual, formação em Psicologia, Doutora em Educação (UDELMARCL/Revalidação UFSCar- SP). Mestre em Psicologia (PUCRS). Especialização Profissional em Psicologia com abordagem Ontopsicológica (SPbU - RU). Docente da Faculdade Antonio Meneghetti - AMF.

${ }^{3}$ Reworking, in 2018, of the reflexions made for the elaboration of the work of conclusión of the Free Trainning in Psychodrama, in 2016.

${ }^{4}$ Reelaboración, en 2018, de las reflexiones realizadas para elaboración de trabajo de conclusión del Curso de Formación Libre en Psicodrama, en 2006.
} 
para el tema de la comunicación/ información en consultoría. El punto de partida es el enfoque de Moreno $(1974 ; 1987)$ sobre comunicación Tele y se completa en la lectura de las informaciones de campo semántico presentadas por Meneghetti (1993; 2010; 2015). El texto propone la comprensión a la luz de fragmentos de un Case. En las consideraciones finales, presenta posiciones relevantes del contrapunto entre los autores y abre la posibilidad al profesional, para que llegue al conocimiento de las causas, a través del conocimiento de Campo Semántico.

Palabras clave: Información. Comunicación. Tele. Campo semántico. Ontopsicología.

\section{Introdução}

\section{Ser Profissional Consultor: minhas inquietações!}

A Graduação que realizei em Psicologia ocorreu na década de 1980. Os enfoques do curso davam ênfase a duas concepções: Behaviorista e Psicanálise, com acenos para a abordagem Humanista. Naquele período, lembro-me que reuníamos alguns alunos interessados em conhecer outras abordagens e fazíamos atividades com profissionais vindos de outros estados. Os professores da Graduação ao tomarem conhecimento ficavam indignados com nossas atitudes, pois eram conhecimentos não bem-vindos naquele momento. Lembro-me de uma ocasião em que fizemos atividades com a Bioenergética e foi uma ocasião de grande tumulto na universidade.

Após formada, fui buscar meu espaço de trabalho. Vi-me trabalhando em uma cidade do interior do Estado do Paraná, sempre buscando sanar aquilo que não compreendia ou que não encontrava nas teorias estudadas na Graduação.

Ao me especializar, meu primeiro contato foi com o curso de abordagem Comportamental. Em seguida, busquei um Mestrado em Psicologia e encontrei professores com as mais diferentes concepções: Psicanalítica, Psicológica Humanista, Psicológica Corporal Reichiana, Psicológica Cognitivista, Psicológica Sócio Histórica, entre outras.

Tudo isso me deixava cada vez mais inquieta. Ouvia os clientes e, ao mesmo tempo, percebia que meu conhecimento não era suficiente para acessar, de modo preciso, aquela informação produzida por meio de imagens e/ou sensações - o que variava em mim com aquela presença, aquela informação - durante o seu discurso verbal. Havia algo a mais que o cliente informava e as teorias não davam suporte para compreendê-lo e auxiliá-lo.

Eu percebia algo mais que as teorias não explicavam e que era de grande valor para trabalhar o caso que se apresentava. Trabalhava com a "intuição"5 e não sabia como utilizá-la,

\footnotetext{
${ }^{5}$ Do latim intus actionis = o dentro ou íntimo da ação. Saber o íntimo da ação. Ver o fazer.

Conhecer os modos ou estruturas interiores de um projeto de ação ou evento. Colher as coordenadas de uma Gestalt. Saber antes dos efeitos" (MENEGHETTI, 2012, p.144).
} 
pois ainda não havia encontrado um autor, um teórico que fizesse entender de modo mais completo o que via, sentia e impactava.

Mais tarde, conheci o Psicodrama, teoria proposta por Moreno. Ao encontrar esse autor descobri que ele abordava a temática da comunicação télica. Porém, ainda assim, não era possível compreender como acessar a linguagem denominada Tele, como era possível chegar à causa daquela comunicação que eu recebia por imagens e sensações, enquanto o cliente verbalizava.

Naquele mesmo período descobri uma teoria que falava da informação de Campo Semântico. Lembro-me que ainda cursava as aulas do Curso de Formação de Psicodrama, e numa das atividades, "virei meu casco pelo avesso e vesti". Ouvia os professores que comentavam: "A Carmen virou do avesso". Percebi que realmente havia mudado algo em mim. Havia encontrado o modo de acessar, com rapidez, aquelas informações que o cliente trazia e não dizia, expressava e não sabia. A informação estava ali e se mostrava por outras vias. Busquei conhecer mais o tema do Campo Semântico e encontrei a Metodologia da Ontopsicologia ${ }^{6}$.

Assim, descrevo neste trabalho, alguns aspectos que enriquecem os conhecimentos daqueles que buscam conhecer o que faz realidade ${ }^{7}$ em cada cliente, ou seja, acessar a informação real no aqui-e-agora daquilo que o cliente descreve e expressa verbalmente, sem ter consciência da causa e que vem expressa e é colhida por outras vias - Campo Semântico.

Portanto, neste estudo tem-se por objetivo articular o conceito desenvolvido pela Teoria Psicodramática sobre a comunicação Tele (MORENO, 1974;1987)) e ampliar o conhecimento para leitura e compreensão das informações através do Campo Semântico (MENEGHETTI, 1993; 2010; 2015), proposto pela Ontopsicologia. Dessa forma, permitir que as informações possam, de fato, produzir o verdadeiro conhecimento que tanto buscamos, o conhecimento da causa.

Diante disso, esta pesquisa se dispõe a fazer um estudo teórico e apresentar uma clarificação para o tema da comunicação/ informação em consultoria. O ponto de partida é a abordagem de Moreno $(1974 ; 1987))$ sobre comunicação Tele e se completa com a leitura das informações de Campo Semântico, apresentado por Meneghetti (1993; 2010; 2015). O texto pretende compreender, ilustrado à luz de fragmentos de um Case.

Na compreensão de Gil (2002), a variação instrumental tem o "propósito de auxiliar

\footnotetext{
6 Para aprofundamento, consultar Meneghetti A. Manual de Ontopsicologia. 4 ed. Recanto Maestro: Ontopsicológica Editora Universitária, 2010.

${ }^{7}$ Realidade: "Propriedade que discrimina o ser do não ser; sucessivamente, especifica os vários modos do concreto" (MENEGHETTI, 2012, p. 232).
} 
no conhecimento ou redefinição de um determinado problema" (GIL, 2002, p.139). Para o autor, o interesse do pesquisador não está diretamente ligado ao caso, mas sim, na sua utilidade para atingir determinados objetivos.

\section{Referencial Teórico}

\subsection{Tele}

A palavra Tele tem origem grega e significa "distância," ou agindo a "distância". Define-se "como uma ligação elementar que pode existir tanto entre indivíduos como, também, entre indivíduos e objetos e que no homem, progressivamente, desde o nascimento, desenvolve um sentido das relações interpessoais (sociais)” (MORENO, 1974, p.52).

Para entendermos a comunicação télica buscamos conhecimentos deixados pelo autor Jacob Levi Moreno (1889 - 1974) e nas contribuições dos seus sucessores. Encontramos nos autores que sucederam J. L. Moreno várias colocações sobre o tema, e as controvérsias estão presentes nas diferentes explicações, com diferentes maneiras de entender o que Moreno propôs ao tratar do tema da Tele.

Em Moreno (1974) consta que a partir dos estudos dos processos grupais, desenvolvidos com crianças (1910 - 1914), com prostitutas (1913-1914) e com refugiados (1915-1917), o autor introduz a ideia de Tele, conforme mostra este excerto: "Um complexo de sentimentos que atrai uma pessoa para uma outra e que é provocado pelos atributos reais da outra - atributos individuais ou coletivos - tem o nome de tele relação." (MORENO, 1987, p. 286).

Em seus escritos sobre Tele, Moreno diz que: "O tele pode, assim, ser considerado como fundamento de todas as relações interpessoais sadias e elemento essencial de todo método eficaz de psicoterapia. Repousa no sentimento e conhecimento da situação real das pessoas" (MORENO, 1974, p. 52).

Em 1914, Moreno escreveu um poema denominado "Convite ao Encontro", cujo texto representa o conceito de Tele. Esse poema descreve como cada participante do grupo pode se colocar no lugar do outro, enxergá-lo e perceber o que está sentindo.

Para Bustos (1979), o conceito tem uma amplitude que não se limita à percepção dos órgãos do sentido. A "tele" envolve aspectos ligados à socialidade, aos afetos, às reações e às sensações corporais, juntamente com a capacidade cognitiva. 
Perazzo (1994), que toma como base um Relatório de Grupo do Primeiro Encontro Nacional de Professores e Supervisores de Psicodrama, afirma que os conceitos fundamentais de Moreno (1974;1987) são: Tele, teoria do papel e espontaneidade e apresenta a seguinte afirmativa: “[...] não há como negar a necessidade de fundamentação teórica sólida do conceito tele. [...] é literalmente espantosa a contradição existente entre a complexidade do tema, sobre o qual é aparente a unanimidade de definição, [...] e a escassez de literatura a respeito do assunto no meio brasileiro (PERAZZO, 1994, p.33). O autor, afirma também, que muito facilmente, a Tele é conceituada como fator, como ramo, até como ramo da própria Tele, como relação, como efeito, como capacidade, como sistema e como sensibilidade. As diversas configurações encontradas para a definição e a compreensão do termo Tele, impedem uma fácil compreensão.

Outra questão apontada por Perazzo (1994) é a ausência de discussões e de estudos sobre o conceito de Tele. Argumenta que são poucas as discussões sobre o conceito, pela maioria dos autores, e que cada um opta por uma das diferentes definições, ou seja, o tema até hoje é evitado "[...] permanecendo confuso na cabeça dos psicodramatistas, de uma maneira geral (PERAZZO, 1994, p. 34).

Para Perazzo (1994), as argumentações de Moreno (1974;1987) sobre Tele ocorrem num determinado momento da relação e se definem como um fator próprio do indivíduo assim como o fator "e" (espontaneidade). Esse canal de comunicação, desobstruindo a transferência, viabiliza o encontro.

As controvérsias e a não clareza das afirmações para comunicação télica, apontadas por Moreno $(1974 ; 1987)$ e pelos autores citados no texto, nos remetem à busca de outros conhecimentos e abordagens que nos possibilitem acessar, com precisão, a informação da realidade do cliente em consultoria.

Assim, se considerarmos os estudos sobre Tele e ampliarmos a maneira de colher a informação de modo exato, por meio do Campo Semântico, teremos uma possibilidade de entrar no mundo da vida, como dizia Edmund Husserl.

Foi a busca pela compreensão das imagens, que permitiu compreendê-las. Esse fato proporcionou conhecimentos que respaldam a questão na sua origem. Assim, chegamos ao conhecimento do Método Ontopsicológico que aborda entre suas descobertas, o Campo Semântico, uma das três descobertas da Ontopsicologia ${ }^{8}$.

\footnotetext{
8 Três descobertas da Ontopsicologia: Campo Semântico, Monitor de Deflexão e Em Si Ôntico. (MENEGHETTI, 2010)
} 


\subsection{Campo semântico 9}

O Campo ${ }^{10}$ Semântico ${ }^{11}$ se define como "comunicação base que a vida usa no interior das próprias individuações.” (MENEGHETTI, 2012, p. 38). Considera-se comunicação base porque é uma informação que ocorre em antecipação aos símbolos: antes dos sentidos, das emoções e da consciência.

Para Meneghetti (2010), as individuações são continuamente geradas pela vida e imersos no contínuo dinâmico que denomina o agente universal. Desse modo, os seres humanos estão imersos em um único campo no qual cada individuação é ponto força que polariza as informações, que, motivadas por uma individuação, de modo consciente ou inconsciente, em um campo, são colhidas por outras individuações que se encontram nesse mesmo campo. Então, continuamente informam e são informadas.

O campo semântico é um transdutor de informações, como descreve Meneghetti: “ $E$ um transdutor informático sem deslocamento de energia: transmite uma informação, uma imagem, um código que, quando chega, estrutura em emoção qualquer coisa vivente, ou organizada em vida, comportando uma variante psicoemotiva orgânica" (MENEGHETTI, 2010. p. 183).

$\mathrm{Na}$ "transdução informática"12 não ocorre a transferência de energia, mas, "o módulo dá a forma de passagem da energia." (MENEGHETTI, 2010, p.183-184). Isso significa que, ao receber a informação, o sujeito receptor varia a sua energia e se formaliza segundo a informação recebida e age com energia própria, a partir da informação colhida de um outro. A informação recebida é sempre neutra, no entanto, o receptor disponibiliza a sua energia para mover a informação recebida. A execução da informação poderá produzir efeitos positivos ou negativos ao executor. Essas consequências dependem da homogeneidade ou não, daquela informação ao útil e funcional para a identidade do receptor executor.

Para complementar, Meneghetti (2010) diz que "com o termo "semântico" entende-se um impulso que, enquanto se move, cria a forma que depois será feita própria como significado pelo receptor ou pelo resultante que chamamos efeitos ou sintoma"

\footnotetext{
${ }^{9}$ Parte do texto foi extraído de um dos itens da tese de doutorado da autora do texto (SPANHOL, 2013) com as devidas complementações necessárias ao enfoque atual.

${ }^{10}$ Campo é um contexto hipotético ou definido por três coordenadas: espaço, tempo e individuação. (MENEGHETTI, 2010, p.182).

11 "Semântico" (gr. Sema = Signo, traço. Mais partícula “ân” que os gregos inseriam para dar movimento à palavra. E "tico" = do verbo "ktizo" que significa posicionar, colocar). Posicionar um sinal dinamicamente. "Sinal da ação naquele lugar; o sinal enquanto se constitui. (MENEGHETTI, 2012, p. 40).

12 Transdução informática: o receptor tem variação psicoemotiva (modifica). Significa que o modulo dá a forma (design) da passagem à (para) a energia, mas não dá a passagem da energia (MENEGHETTI, 2012).
} 
(MENEGHETTI, 2010, p. 183). Para o autor, é a partícula an da palavra semântico que fortifica o termo. Desse modo, o "outro" se faz presente dentro, antes que se colha o signo externo.

\begin{abstract}
Por "semântico" (de sema) se entende um especificar-se da realidade. O real chega codificado de modo inequívoco: uma carícia, um pontapé, uma indiferença, um medo etc. A realidade do indivíduo não chega de modo caótico, mas é sempre um exato formalizado sensível. A vida não conhece o desperdício, move-se segundo princípios de economia energética: tanto serve para comunicar, como emana de impelência ou impedância energética, sempre formalizada ao detalhe e traçada em modalidade organísmica. Portanto, "semântico" no sentido de significância, para denotar que a comunicação é em ato (MENEGHETTI, 2005c, p.37).
\end{abstract}

Para Petry (2003, p. 31), o conhecimento do Campo Semântico é possível, uma vez que, ao ocorrer o encontro entre dois entes, se estabelece uma unidade de campo "onde toda a variação energética de um é interceptada pelo radar-corpo do outro". Essa informação da variação energética ocorre mesmo que o indivíduo não tome consciência do ocorrido. Para ler as informações de Campo Semântico, o indivíduo deve usar o próprio corpo. Precisa atentar também, para esse radar que colhe informações, em que uma se apresenta como prioritária a cada momento. Convém apresentar um terceiro conceito proposto pelo autor, o qual diz que: "O campo semântico é conhecimento sensório-viceral e é uma informação que se estrutura no corpo como medianicidade de intenção real." (MENEGHETTI, 2010, p.190, grifo do autor).

Em uma de suas explicações sobre o tema, Meneghetti (1993) afirma: "um campo semântico é o deslocamento de intencionalidade psicoenergética de um indivíduo (mandante) para outro (executor). O mandante (instigador ou primeiro ativante), expõe uma pulsão própria, consciente ou inconsciente, interiorizando-a no psicorgânico da pessoa colônia partner (MENEGHETTI, 1993, p.9).

Por exemplo: se observamos a ação de um portão movido por um controle remoto, ao acionarmos o controle, ele emite um sinal que é captado no motor do portão, fazendo com que se mova com sua própria energia, e o portão se movimenta. Mas para que isso ocorra, ambos - controle remoto e portão - precisam estar na mesma frequência, ou seja, em sintonia.

No executor-colônia, a ação-impulso sofrida é percebida e executada como motivação própria ou egóica. O semantizado executa o outro, isto é o passivo identifica psicorganicamente motivações precisas de outro. Geralmente essa interação é filtrada e conduzida pelo poder constelador dos complexos no âmbito subconsciente. A capacidade causadora sobre o eu do passivo é tal que ele sente como pulsão instintiva própria aquilo que, ao invés, é a exigência psicorgânica do "partner" próximo. Trata-se, de uma pulsão transferida de um organismo a outro (MENEGHETTI, 1993, p. 9). 
Se usarmos o exemplo do portão, para compreendermos o comportamento dos seres humanos, veremos que ele ocorre de modo semelhante. O indivíduo "A" dispara um sinal intencionalidade -, o indivíduo "B”, percebe um desconforto, mas não compreende e executa a ação da intencionalidade do indivíduo "A".

Para Meneghetti (2015, p.13), "Não podemos considerar objetiva nenhuma pesquisa sobre o humano, se o pesquisador não tem experiência dos campos semânticos." O autor considera que os escritos sobre a teoria Ontopsicológica, são incompreensíveis ao pesquisador se este, não conhece a existência da realidade dos campos semânticos.

Meneghetti salienta que durante a prática clínica observava que o paciente, à sua frente era diverso daquilo que aparentava. "O paciente aparecia de um modo e existia de outro". (MENEGHETTI, 2015, p. 16). Por mais que permanecesse em escuta atenta, frequentemente, surgiam distrações e fantasias. Assim, iniciou, de modo sério, a pesquisa sobre tudo aquilo que logicamente tendia a excluir: "Não se tratava de anular a razão, mas de investi-la em zonas consideradas irreais, não existentes.” (MENEGHETTI, 2015, p. 17, grifo do autor). Ainda, segundo o autor, "Qualquer poder sobre a matéria está na ordem psíquica, porém é preciso primeiro aprender o acesso a ela. A psique tem leis que são as mesmas que regulam o universo.” (MENEGHETTI, 2013, p.51).

Segundo Meneghetti (1993):

Toda energia se baseia sobre um agente universal que é também vibração de espaço fluído. A sensação viscerotônica, ou cerebrotônica de um campo semântico, constitui-se por alteração ou variação dos elétrons dos corpos celulares de uma determinada zona (correspondente a uma exigência instintiva do emissor); a vibração causa deslocamentos sincrônicos e específicos no espaço fluído ambiente. A onda produzida no ambiente fluído, iguala-se aos elétrons dos corpos celulares de determinadas zonas do destinatário, correspondentes àquelas do emissor. O sistema de propriocepção do destinatário, recebe como sensação própria a informação do outro, desta adquire consciência própria e, na sua pseudo-espontaneidade, se determina em resposta ao outro (MENEGHETTI, 1993, p. 11-12).

Conforme escreve Vidor (2013, p. 60), “A variação de ondas percebidas pelo Campo Semântico especifica informações adequadas à vida humana, de variações que modificam a ordem e as funções organísmicas ${ }^{13}$."

\footnotetext{
${ }^{13}$ Organísmico: implica a alma; ism deriva do grego eìuí (verbo "ser”), do qual vem ö $v \tau o ́ \varsigma$ (ôntico). É uma raiz particular que indica a espiritualidade, a qual se pode traduzir também em funcionalidade. Ver: MENEGHETTI, A. Presença do Em Si ôntico no orgânico humano. 2010, p. 21; 2012, p.198. "Conjunto de funções materiais e psíquicas para uma unidade de ação. Contexto psicobiológico e espiritual" (MENEGHETTI, 2012, p. 198). “Organísmico" é um termo próprio da Escola Ontopsicológica que define a unidade de consciência em ato orgânico. "O organísmico é o sincronismo entre a alma e corpo, percebido como tomada de consciência unitária” (MENEGHETTI, 2005a, p. 29, 95).
} 
O Campo Semântico se formaliza por imagens ${ }^{14}$. O mundo é feito por imagens, tudo procede por imagens. Imagem: “Como a forma age em mim ou em outro." (MENEGHETTI, 2012, p.131). Por imagem, o autor não entende aquela que expressa atos de criatividade ou fantasias, mas fala das estruturas que permitem quaisquer variáveis energéticas.

A energia se formaliza nas imagens e é um conhecimento sensorial-visceral. A informação de Campo Semântico se dá de inconsciente para inconsciente e é sempre neutra, ou seja, nem positiva, nem negativa. Contudo, será positiva ou negativa, segundo a posição do receptor ou os efeitos produzidos no receptor. Experencialmente colhemos o Campo Semântico das seguintes maneiras: a) recuperando a consciência sensória visceral e a consciência holística organísmica; e b) com o cuidado (cura) do prazer estético; (respeito com o corpo, imagens que vemos, jornais, etc. e higiene com função estética).

Com a recuperação da consciência sobre a "comunicação base que a vida usa no interior das próprias individuações" (MENEGHETTI, 2012, p. 38), foi possível identificar as pulsões do inconsciente dos clientes. A pesquisa deste tema permitiu verificar a existência de duas realidades: uma pulsão, que quando seguida pelo cliente, o tornava mais saudável, com maior vitalidade em progresso e uma outra pulsão, que indicava rigidez e repetição. Quando o cliente seguia esta segunda, regredia e adoecia. Por um lado, a pulsão que portava vitalidade e evolução ele denominou Em Si Ôntico; por outro lado, a pulsão que indicava rigidez, regressão, denominou Monitor de Deflexão. Assim, da prática clínica o autor chegou as outras duas descobertas: Em Si Ôntico e Monitor de Deflexão.

\section{Informação no contexto da Consultoria}

O que é informar? O que é comunicar? A qual informação nos remetemos?

Ainda, no contexto da consultoria, como o profissional "decifra", por assim dizer, o que o cliente informa - comunica? Tudo o que o cliente diz é de fato significativo para sua existência? Qual é a verdadeira informação/comunicação e como acessá-la?

A criança, enquanto não se expressa por meio de dimensão lógica e racional apreendida pela linguagem verbal, usa o recurso da sensação e percepção para compreender o meio que a circunda. Schutzenberger (1997, p. 85), explica que "as crianças e os cães da casa

\footnotetext{
14 "O igual energético se especifica em vetorialidades, as quais se perfilam como projeção geométrica do colocar-se energético. A imagem é a projeção geométrica de uma vetorialidade em ato." (MENEGHETTI, 2010, p. 53).
} 
sabem tudo..." Uma vez que, na infância, ainda não sofrem as pressões conscientes impostas pela realidade social, as crianças são capazes de responder ao mundo pela informação base.

Uma informação ${ }^{15}$ que nós, adultos, desaprendemos porque não damos a devida atenção às novas variações organísmicas e enfatizamos sobremaneira, aquilo que a lógica racional nos permite ver. Assim, perdemos o básico da comunicação que não é verbalizado, não é expresso em atos, mas é vibração que se processa no campo das relações e que move, muitas vezes, com mais força do que palavras ditas.

Meneghetti (1993), em relação à comunicação base enfatiza que:

O consciente é a reflexão do ato especificado da vida. Mas por causa do predomínio da instância sócio-histórica, o consciente não é mais a reflexão da exata do seu real especificado. $\mathrm{O}$ consciente por ter sofrido a reflexão da e exigência autoritária sóciohistórica, colhe o próprio ato somente segundo a ótica preferencial sócio-histórica e do social organizado, segundo todos os processos ou sedimentações de um coletivo em contínua metamorfose. Com esse contexto o eu ou o consciente, de fato, fica impotente perante o ato que afunda o existencial. $\mathrm{O}$ eu dividido do ato vida, padece a angústia, com a suspeita de um paraíso perdido. (MENEGHETTI, 1993, p.17).

Convém ressaltar que comunicar é muito mais que a nossa mente consciente consegue absorver, pois comunicamos, informamos e recebemos informações de inconsciente para inconsciente. Essa é a comunicação base, que vem antes de qualquer emoção, de qualquer linguagem. Portanto, para que de fato a informação seja precisa, é necessário que saibamos lê-la.

Como foi apresentado anteriormente, no item 2.1, Moreno $(1974 ; 1987)$ apresenta a comunicação Tele como uma ligação elementar entre os indivíduos. No item 2.2, Meneghetti (1993; 2010; 2015) destaca que pela leitura das informações do Campo Semântico é possível identificarmos essa comunicação.

Para Meneghetti (2005b),

O erro essencial de toda a psicologia e pesquisa humanística conquiste na falta de exatidão de consciência. Quase todos os seres humanos, quando julgam, quando relevam, tem uma consciência não correspondente ao fato existencial. [...]Dei-me conta que a natureza projeta muitos dados, códigos de leitura, emoções estados biológicos, químicos, morais; isto é, por como homem é consciência colhe somente alguns deles; além disso, os lê de maneira distorcida: a consciência não sabe ler de modo exato o apelo do instinto. [...] A tarefa universal da psicologia cientifica é tomar exato o $\mathrm{Eu}$ ou a consciência à percepção total do fato existencial (MENEGHETTI, 2005b, p. 12-14).

De acordo com Meneghetti (2005b), cada indivíduo projeta o modo estrutural de sua presença no impacto com outro ser humano. Ele "faz comunicação" a partir do próprio

\footnotetext{
${ }^{15}$ Cf. MENEGHETTI, A. Ontopsicologia Clínica. 2005e, p. 275-278.
} 
configurado real que é uma comunicação física, uma vez que no universo cada coisa vivente está em comunicação porque existem as vias da comunicação base da vida, que transmitem e recebem todas as informações. Ao homem é permitida a capacidade de colher essas informações por inteiro, pois cada sentido humano impacta sempre os outros reais. Para isso, basta que resgatemos e saibamos como colher essas informações que são sempre coincidentes como o real.

Meneghetti (2012) diz que esta é a comunicação base que a vida usa ao interno das próprias individualizações, a qual denomina Campo Semântico. "É a informação base que acontece antes de todos os sentidos, antes de todas as emoções, antes de toda a consciência, em antecipação a qualquer símbolo" (MENEGHETTI, 2012, p. 39).

As informações que tocam nosso corpo, são colhidas de imediato por nosso cérebro vicerotônico - órgão do qual somos dotados de modo exato. Diferente do cérebro localizado em nosso crânio, as informações que tocam nosso vicerotônico portam uma informação primeira, sem distorções, obsessões, estereótipos ou memes.

Então, se resgatarmos e desenvolvermos a primeira comunicação, a comunicação base que nos faz perceber aquilo que faz realidade em nós, o que se opera em nós, estaremos realmente, compreendendo o que nos é comunicado, informado.

Para recuperar o primeiro critério objetivamente, o critério ôntico da própria verdade de natureza, a Ontopsicologia propõe a recuperação do conhecimento organísmico: saber ser íntima consciência do próprio orgânico de modo total. O corpo é a palavra de um projeto eterno: quem colhe o projeto, a estrutura, colhe o arquiteto. Nesta palavra que é o nosso corpo, se encontra a pedra angular sobre a qual está baseado todo o edifício da nossa existência (MENEGHETTI, 2016, p. 388).

Um profissional, na consultoria, para compreender as informações emanadas pelo cliente precisa estar exato com sua vida. Ao individuar a informação de modo preciso, auxilia o cliente a encontrar sua verdadeira estrada e a reconhecer as informações que lhe permitem ir adiante ou regredir.

Desse modo, quando utilizarmos toda a informação básica que se processa em nós, com estratégias adequadas na lógica consciente, estaremos usando todo nosso potencial para decidir adequadamente, sobre as escolhas que a vida nos propõe. Isso nos possibilitará viver dentro da nossa real possibilidade humana, enquanto Ser e existência, aquilo que é real ${ }^{16}$ faz realidade em nós, ao contrário, não existe.

\footnotetext{
${ }^{16}$ Real (do latim res = a coisa, alea = o lance, o ímpeto) significa: a noção como a coisa, tem a verdade quando lançada. (MENEGHETTI, 2014, p. 52). Todo real é um nexo ontológico formalizado (MENEGHETTI, 2015, p.60).
} 
De acordo com Meneghetti (2000, p. 462, tradução nossa) que: "para colher o campo semântico, é preciso ser saudável, isto é, precisa ser um instrumento quase perfeito, senão, não é possível colhê-lo. Com o termo 'perfeito', quero dizer que um sujeito é sadio, é bem feito para as suas necessidades, para a suas funções, é um ser humano que funciona por si mesmo".

O homem é um projeto exato e perfeito da vida, mas por perder a coincidência com o seu potencial de natureza, erra sempre e não se encontra conforme a identidade da natureza, por tantos erros cometidos ao realizar ações e escolhas no contexto da sua existência. Desse modo, perde a transparência de seu real potencial e se fixa em regras e normas que já se encontram incrustadas em seu viver, nas quais acredita e que orientam e a guiam a sua vida. $\mathrm{O}$ ser humano vai sendo "formado de fora", de um externo a ele, o que lhe permite muitas funções, mas ao mesmo tempo, não lhe ensinam a auscultar a si mesmo. É como a metáfora: “o automóvel é bom, mas é o sistema de direção, aprendido de 'fora' que é errado". Lembremos que "este automóvel" é todo o potencial de vida humano. Por isso, a necessidade de um ser humano sadio e exato com sua identidade de natureza para poder verdadeiramente, operar no sistema social, fazer as leituras das mais diversas informações com as quais impacta no conjunto das relações sociais e produzir um critério de veracidade na ciência.

Dessa forma, no contexto da consultoria, percebemos que saber ler o que o cliente comunica é também uma Arte, a qual só a tem quem está dentro de si mesmo. Entretanto, para estar em si mesmo é preciso viver a autenticidade da vida que brota em cada um, o que permite colher a lógica da vida, o critério de natureza ${ }^{17}$ - Em Si Ôntico - para isso, basta ser simples. É preciso demostrar que é exato na sua existência e age em conformidade com o seu projeto de natureza, atuando como funcionalidade circular a si mesmo (MENEGHETTI, 2010, p.143).

O cliente comunica sua história, seus fatos cotidianos, mas quando o faz, engana a si mesmo porque está sempre "se vendo com os olhos" que já conhecem todo o percurso. Ao dizer, não diz. Ao não dizer, fala, se move como o sopro do vento que não aparece, mas que move tudo ao seu redor. E, quanto mais intensa essa força, mais fortemente envolve quem está desatento e entra no "embalo".

Schutzenberger (1997, p.74) pontua que Freud já lembrava que "aquele que têm olhos para ver e ouvidos para ouvir percebe que os mortais não conseguem guardar nenhum segredo

\footnotetext{
${ }^{17}$ Critério de natureza é uma medida que procede por evidência[...]. É a intencionalidade de natureza quando e como se evidencia. (MENEGHETTI, 2010, p. 147).
} 
(...). Aquele, cujos lábios se calam, fala demais com as pontas de seus dedos. Ele se trai por todos os poros".

\section{Fragmento - Case I}

Em minha atividade de consultoria atendi uma cliente que lamentava os seus projetos não realizados. Ela contava sobre o último projeto que havia sido rejeitado. Os insucessos eram tantos que ela já pensava em mudar de atividade, seguir os planos do marido e auxiliar nos afazeres dele, a cuidar dos seus projetos.

Meneghetti (2011) esclarece: “enquanto ouço o cliente, não me sirvo apenas de todos os critérios racionais, mas também da leitura da semântica ôntica ${ }^{18}$. O sujeito que tenho diante de mim emana realidade, determina uma variação de campo, altera as minhas conotações informáticas, impacta-me determinando um sentido e uma situação interna” (MENEGHETTI, 2011, p. 219).

Retornando ao relato acima, enquanto meu "eu profissional" estava atento em sua história, em suas preocupações, em uma sutil aparente distração, visualizei uma imagem, numa fração de segundos - uma gestalt. Um instante como num flash - e a imagem me chamou: "uma garota de 3 a 4 anos, cabelos louros cacheados, com vestido rosa olhando um livro ou algo parecido, numa sala com uma estante e um homem ao seu lado".

Segundo Meneghetti (2010), “a imagem é o formal do quântico. Quando se interpretam ao sonhos, a psicossomática, os lapsos e tudo aquilo que é fenomenologia do sujeito, colhem-se os formais que especificam quânticos em ação. $\mathrm{O}$ traçado dos quânticos formais constitui a imagem" (MENEGHETTI, 2010, p.53).

Na compreensão de Meneghetti (2000, p. 462), “o campo semântico aparece na consciência como uma associação livre, ou seja, aparece uma imagem que parece não ter nenhuma relação racional, se alterna de modo ilógico, não coerente. Além disso, é uma

\footnotetext{
18 Semântico: “do grego significa signo da ação naquele lugar; o signo enquanto se constitui. Significa: significância. Faz signo, especifica ação e se presencia. A energia se move segundo uma direção exata: escopo ao intrínseco objeto. Por semântico entendemos a virtualidade, a capacidade de pôr em ato efeitos segundo a informação exclusiva do intencionante vetorial, isto é, ato com efeito segundo o primeiro significante. É um impulso que - enquanto se move - cria a forma que, depois, será sofrida como significado pelo receptor. A energia se formaliza nas imagens. A imagem é o símbolo que a energia usa ao interno de si mesma para fazer qualquer variável". [...] "Um campo semântico é emissão de informações com efeito psíquico, emocional, elétrico no campo de um outro organismo [...]. Cada um de nós é um campo semântico e se encontra entre múltiplos campos semânticos; cada um emana e recebe pulsões, comunicações com mensagens precisas. Nós somos pontos de referimento de um contínuo dinâmico" (MENEGHETTI, 2012, p. 40-43).
} 
imagem que se forma, porém é gestáltica, isto é, uma forma que individua um lugar completo, vivo, não estático, em ação ${ }^{19}$.

\begin{abstract}
Portanto, a imagem gratuita, sem sentido, se sustenta ao racional do sujeito. Para qual forma-se duas estradas: uma racional e documentada, e a outra, é uma associação que faz intuir. Esta gestalt fisionomiza uma outra história, outra identidade que o sujeito naquele momento não entende minimamente. Isto é, o campo semântico associa a qualquer gênero de verbalização, de presença, um outro endereço, uma outra indicação que é substancial, o radical de todo o sujeito, de toda a situação (MENEGHETTI, 2000, p. 462).
\end{abstract}

Então, primeiro me perguntei que imagem era essa? "As imagens são projetos quânticos ${ }^{20}$ em ação. 'Projeto' é um arremessar para, dinâmica para, inexorável ao específico efeito" (MENEGHETTI, 2010, p. 594-55) 21. Portanto, estabeleci uma hipótese para a situação relatada acima: a imagem vista pode ter algo a ver com essa cliente!

Segundo Meneghetti (2000, p. 463), “o campo semântico mostra-se antes como uma cena a si, em parte; naquele momento trata-se de tomar uma decisão: deixar-se emocionar ou vê-la apenas. E boa regra vê-la sem deixar-se emocionar, ou seja, imaginar como um holograma sobre um espaço que aparece vagante".

A imagem gestáltica da informação que se processa e é colhida no inconsciente do outro - consultor -, se manifesta no seu todo organísmico. Ao lê-la adequadamente, o profissional tem a chave-estratégia de racionalidade para aplicar a favor do cliente.

Então, eu consultor, comecei a indagar, investigando primeiro, indutivamente, até chegar a deduzir.

\begin{abstract}
Portanto, enquanto se está falando ou escutando, é preciso ter presente estas imagens que aparecem ao improviso e depois desaparecem. Porém não é necessário fixar-se, é necessário permanecer o sujeito, mesmo por que estas imagens aparecem na medida em que se segue sempre o sujeito. A atenção deve estar sempre ao redor disto que o outro fenomeniza, porém, com este "terceiro olho", se está atento na novidade desta imagem, porque a verdade última com o qual se tem que fazer é isto que aparece nesta imagem fugaz. $\mathrm{E}$ para ver, não precisa investir-se. (MENEGHETTI,2000, p. 463).
\end{abstract}

Segue a continuação do diálogo com a $(\mathrm{C})$ :cliente e $(\mathrm{PC})$ : profissional consultor.

PC- "Como era seu cabelo quando criança?"

C- "Era ruivo".

\footnotetext{
${ }^{19}$ É gestáltica, por isso é uma ação com imagens em ato, completa.

${ }^{20}$ Quântico - implica em variação de energia.

21 Imagem: "do latim - in me ago, ajo em mim. [...] Projeção geométrica de um quântico em ação; forma especular da ação em curso. A estrutura portanto, é diferenciadora de um quântico energético. É a direção, o modo do quântico de uma energia. Projeção geométrica de um fato ou de um objeto. O sinal projetado pela ação ou coisa; e vice-versa, a ação ou coisa como se projetam, como se refletem na minha consciência" (MENEGHETTI, 2012, p. 131).
} 
PC- "Cacheado?"

C - "Sim".

PC - "E a sua casa, na infância... Nela havia uma sala com estante de livros?"

C - "Sim".

PC - "Você tem lembrança de alguma roupa sua de quando tinha 3 ou 4 anos?"

C - [descreve um vestido cor-de-rosa tal com a imagem].

PC - "Lembra de seu pai estar com você nesta sala lendo livros ou contando histórias?"

C - "Lembro que ele costumava me mostrar suas fotos de quando foi jogador de futebol”.

Naquele momento, a cliente retomou um fato histórico: seu pai fora jogador de futebol e parou de jogar porque sofreu um acidente, e lembra que ele lamentava, por ser sua grande paixão, ou seja, um projeto frustrado.

Ao escrever a obra "Meus antepassados" Schutzenberger (1997) traz uma citação de Dolto (1985, p. 446), que diz: "todo filho é obrigado a suportar o ambiente em que cresceu, bem como os efeitos patogênicos, deixados como sequelas do passado patológico de sua mãe e deu seu pai" (SCHUTZENBERGER, 1997, p. 46).

Essa passagem encontra respaldo teórico em:

Somos afinal, de certa forma, menos livres do que acreditamos. Entretanto, podemos reconquistar nossa liberdade e sair da repetição, ao compreender o que aconteceu, ao distinguir esses fios no seu contexto e na sua complexidade. Podemos, enfim, viver 'nossa' vida e não a de nossos pais ou avós nem a de um irmão falecido, que vamos substituindo, consciente ou inconscientemente (SCHUTZENBERGER, 1997, p.11).

Porém, é com a leitura de Campo Semântico, destacada por Meneghetti (1993; 2010; 2015), que acessamos as informações que nos permitem ver quando o indivíduo repete a história dos seus antepassados, conforme apontado por Schutzenberger. Assim, ao repetir a história não cria a novidade de ser pessoa - essere per si.

Meneghetti (2000, p. 463), argumenta que: “a pessoa não saberá, nem verá destruição ou vantagem, porém, quase sempre, o campo semântico não entendido torna-se dano para o sujeito. Não compreender o campo semântico significa estar arruinado da própria vida, porque o sujeito. [...] se põe contra a verdade de si mesmo." Neste trecho o autor acrescenta: "não sigo as suas palavras, mas a sua realidade que ele não conhece". 
A informação é transmitida a cada instante pelo cliente. Ele não sabe ler, muitas vezes, por isso, distorce e vive mal sua história porque vive o "outro" que não é ele, mas o vive como se ele fosse.

Schutzenberger (1997, p.10) destaca que "continuamos a cadeia das gerações e pagamos as dívidas do passado; enquanto não 'se apagou a lousa', uma 'lealdade invisível' nos impele a repetir, queiramos ou não, saibamos ou não, a situação agradável ou o acontecimento traumático ou a morte injusta, trágica até, ou o seu eco".

Para Meneghetti (2010),

A forma é direção, o quântico e o modo de uma energia. 'Forma' é o percurso segundo o qual a energia deve acontecer. A vida, quando age, é sempre formal. Quando a energia se move, está em convivência com uma forma ou imagem que lhe dá a direção. 'Imagem' significa a ação que está me fazendo, ou que está sinalizando em mim. A imagem é a estrutura portante e diferenciadora de um quântico de energia; é o código que faz ser ou não ser aquele modo de energia; é o alfabeto de sentido do discurso energético, de modo universal - e específico - no ser humano (MENEGHETTI, 2010, p. 57)

Portanto, segundo Meneghetti:

Partindo da imagem, eu tenho e posso controlar a dinâmica, o quântico dinâmico, o real, a densidade, a matéria, a energia. Partindo da dinâmica, eu tenho a energia, o quântico, a matéria e posso chegar à imagem. Imagem e matéria, imagem e dinâmica, imagem e energia, são double face de uma única realidade (MENEGHETTI 2006, p. 265).

A análise que se faz aqui é que a imagem condensada que surge quando a cliente se expressa, traz à tona uma informação recebida na infância, dinâmica, com a qual ela se move hoje. O pai informa sua frustração - projeto não realizado -, à filha ainda na infância. Essa informação a acompanha até aquele momento, o que a faz viver do mesmo modo que ele tendo agora os seus projetos frustrados.

Para Meneghetti (2010), “a imagem é a ordem determinante da energia aplicada. Essa energia $^{22}$ não é ao acaso, mas tem um voluntarismo que a preestabelece em um modelo de comportamento. O comportamento é imagem. A energia sem imagem não pode existir, enquanto a imagem pode determinar também a energia" (MENEGHETTI, 2010, p. 57).

Naquela situação, foi apontado à cliente a informação da infância que a fez repetir a história do pai. Ao compreender aquela passagem de sua vida, ela se retomou. A partir daquele momento começou a agir de outro modo com seus projetos. Hoje, vive das stas

\footnotetext{
${ }^{22}$ Energia: "Do grego $=\mathrm{o}$ dentro do trabalho. Presença de força. Ecceidade da possibilidade Semovência de um quântico. Capacidade de efetuar" (MENEGHETTI, 2012, p. 93).
} 
atividades desenvolvidas a partir de seus projetos. Faz-se necessário então, ser autêntico e ter espontaneidade, fazendo a novidade de ser a cada instante, sem viver a história por repetição.

Segundo Meneghetti (2010, p. 57), “Quem possui o conhecimento das imagens tem o poder da energia. Possuir o código da imagem significa colher a reversibilidade entre imagem e energia e entre energia e imagem".

No relato descrito a cliente trazia em si uma informação que estava latente e que se movia sem que soubesse dela. Essa informação a fazia viver uma história repetida, de um modelo que se instalou e que a absorvia repetidamente, mesmo que almejasse outra direção. Essa força contida na informação - informação à ação -, faz com que o indivíduo se mova contra si mesmo proporcionando a auto sabotagem.

Nos escritos de Schutzenberger (1997, p. 66), encontramos que: "as fontes de repetições ficam sem tomada de consciência ou racionalização do que se passa. Em compensação os segredos de família se investem de libido e determinam profissões, escolhas de passatempos ou de diletantismos".

Argumenta Meneghetti (2006):

Toda a arte superior de alta psicologia é possível exatamente por este princípio. Tem-se o poder sobre a imagem na medida que se tem o poder sobre a energia e se tem o poder sobre a energia na medida que se tem o poder sobre a imagem. Caso se queira parar um estímulo, parar um instinto, deve-se destruir a imagem. É inútil colocar-se a contra-estimular, é preciso ter a chave da imagem (MENEGHETTI, 2006, p. 266).

Em relação a esse aspecto podemos dizer, com base em Meneghetti, que pela informação semântica recebida o indivíduo faz escolhas segundo uma seleção temática que o aproxima do mesmo modelo diádico da primeira informação ou as primeiras informações vividas na infância. Embasada no modelo de díade vivido e aprendido na infância, preestabelece-se a coação a repetir esse modelo nas demais relações que o indivíduo estabelecerá ao longo de sua vida, pois a partir daí, se delimitará o modo pelo qual ele passa a conhecer a si mesmo, aos outros, às relações e ao mundo.

Enquanto profissionais Consultores, para colhermos adequadamente a realidade que move aquele ser, é preciso ter presente que as informações que recebemos, escutamos e auscultamos, requerem um reconhecimento de que colhemos o cliente como o todo do nosso organísmico (dimensão orgânica, psíquica e espiritual). 


\section{Considerações Finais}

Ao descrevermos os fragmentos do Case I ficou evidente que, para compreender a real causa que move os clientes, não é suficiente a comunicação descrita por Moreno (1974;1987), que envolve o conceito de Tele. Entretanto, requer do profissional a compreensão da informação de campo semântico. Conhecimento que possibilita ver o cliente de modo "transparente".

Estar atento ao que o cliente diz ou manifesta na expressão ou movimentos, auxilia o consultor a encontrar um caminho para acessar o seu interior, mas nem sempre é possível, pois o cliente foge do ponto que o limita. Portanto, nessa hora, a comunicação base é que dá a direção exata a ser seguida porque informamos a cada instante, estamos sempre emanando endereços. A variação organísmica que sentimos e nem sempre conscientizamos é sinal de que estamos recebendo informações emitidas por outras pessoas.

Decodificamos a realidade circundante (o mundo) ao nosso redor por meio de imagens (do latim in me ago = ajo em mim). Recebemos o externo (percepção exteroceptiva) e por meio de sinapses, que são únicas para cada indivíduo (percepção proprioceptiva), um condensado de informações que são lidas pelo nosso cérebro, para depois serem expressas (percepção egoceptvia).

Ocorre que, como tudo se dá por imagens, cada indivíduo tem o registro de uma imagem matriz, que se antecipa e deflete a nova imagem e faz o recorte da realidade, deformando, segundo aquilo que já preexiste. Então, o que faz a realidade para o indivíduo, o impacta, o emociona é por seleção pré-estabelecida pela imagem matriz, levando-o a repetir os mesmos enganos.

Se colhermos a imagem antes dela ser defletida ou deformada, temos condições de atuar na causa em que se move a energia empregada para aquela ação. Então, ao interferir na imagem podemos interferir na dinâmica que está se deslocando e agir no processo, ou seja, imagem e energia andam juntas, se movemos uma, movemos a outra e vice-versa - processo de reversibilidade. Portanto, ter o poder da imagem é possuir a fórmula para interferir na dinâmica em ação naquele indivíduo.

A proposta de considerar as imagens colhidas no processo da consultoria, articular o conceito desenvolvido pela Teoria Psicodramática sobre a comunicação Tele (MORENO, 1974;1987) e ampliar o conhecimento para leitura e compreensão das informações, através do Campo Semântico (MENEGHETTI, 1993; 2010; 2015) proposto pela Ontopsicologia, permitem tecer algumas considerações: 
1 - o conceito de Tele indica um modo de comunicação pelo qual os indivíduos comunicam algo que não se faz visível como fenômeno palpável pelos cinco sentidos da percepção;

2 - Moreno $(1974 ; 1987)$ não propõe um método para aplicar e utilizar a informação da comunicação télica;

3 - a proposta de Schutzenberger (1997), que atua em análise clínica grupal e no Psicodrama, com uma visão transgeracional e psicogenealógica contextual, apresenta um indivíduo que precisa "pagar dívidas" do passado. É uma espécie de "lealdade invisível com os antepassados. Porém, não é claro como acessar em antecipação as informações que causam danos;

4 - o conceito de Campo Semântico define, precisamente, o que é e como se processa a informação base que ocorre entre as individuações;

5 - o autor A. Meneghetti (1993; 2010; 2015) propõe um método que possibilita ao pesquisador exato, colher as informação base. "Para objetivar com exatidão, o homem de ciência deve sair do mundo da objetividade e ser perene subjetividade; [...] Faz-se ciência exata quando a egoceptividade coincide com a propioceptividade" (MENEGHETTI, 2010, p. $142)$;

6 - o uso adequado das informações colhidas, permitem acessar o real do cliente e darlhe a chave de acesso à causa para solucionar os seus "problemas".

Assim, considera-se que o conhecimento proposto pela Ontopsicologia amplia a possibilidade de leitura das informações, pois permite ao profissional na sua ação "colocar-se em escuta das causas primeiras" (SPANHOL, 2017, p. 346) frente às demandas do cliente, e, assim, efetivamente propor diretivas que permitam o reencontro com a vida que cada um porta, permitindo o crescimento ou regressão por livre escolha na decisão existencial.

\section{Referências}

BUSTOS, D. M. O teste sociométrico. São Paulo: Brasiliense, 1979.

GIL, Antonio Carlos. Como elaborar projetos de pesquisa. 4 ed. São Paulo: Atlas. 2002.

MORENO, J. L. Psicoterapia de grupo e Psicodrama: introdução à teoria e à práxis. São Paulo: Mestre Jou, 1974.

MORENO, J. L. Psicodrama. São Paulo: Cultrix, 1987.

MENEGHETTI, A. Campo Semântico. Porto Alegre: ABO, 1993.

MENEGHETTI, A. La Cinelogia, Cinema e inconscio. Roma: Psicológia Editrice, 2000. 
MENEGHETTI, A. Manual de melolística. Recanto Maestro: Ontopsicologia Editrice, 2005a.

MENEGHETTI, Antonio. Pedagogia Ontopsicológica. Conferência proferida no Recanto Maestro, 31 de dezembro de 2005 (Informação verbal de curso) (2005b).

MENEGHETTI, A. Cinco Lições de Ontopsicologia. Recanto Maestro: Ontopsicológica Editrice, 2005c.

MENEGHETTI, A. A psicossomática na ótica ontopsicológica. Recanto Maestro: Ontopsicológica Ed. 2005d.

MENEGHETTI, A. Ontopsicologia Clínica. Recanto Maestro: Ontopsicologica Ed. 2005e.

MENEGHETTI, A. Imagem alfabeto da energia. 4 ed. Recanto Maestro: Ontopsicológica Editrice, 2006.

MENEGHETTI, A. Manual de Ontopsicologia. 4 ed. Recanto Maestro, RS: Ontopsicológica Editora Universitária, 2010.

MENEGHETTI, A. O Projeto Homem. 3 ed. Recanto Maestro: Ontopsicológica Editora Universitária, 2011.

MENEGHETTI, A. Dicionario di Ontopsicologia. 2 ed. Recanto Maestro: Ontopsicológica Editora Universitária, 2012.

MENEGHETTI, A. Genoma Ôntico. 3. ed. Recanto Maestro, RS: Ontopsicológica Editora Universitária, 2013.

MENEGHETTI, A. Campo Semântico. 4. ed. Recanto Maestro, RS: Ontopsicológica Editora Universitária, 2015.

MENEGHETTI, A. O Residence Ontopsicológico: práxis e filosofia existencial. 4 ed. Recanto Maestro, São João do Polêsine, RS: Ontopsicológica Editora universitária. 2016.

MORENO, J. L. Psicoterapia de grupo e Psicodrama. São Paulo: Mestre Jou, 1974.

PERAZZO, S. Ainda e sempre Psicodrama. São Paulo: Agora, 1994.

PETRY, A. M. A nova abordagem do complexo de édipo. 124 f. Trabalho de Conclusão de Curso (Especialização) - Faculdade de Psicologia. Universidade Estatal de São Petersburgo, Rússia, 2003.

SCHUTZENBERGER, A. Meus Antepassados: vínculo transgeracionais, segredos de família, síndrome de aniversário e prática do genossocigrama. São Paulo: Paullus, 1997.

SPANHOL, C. I. D. Significados e sentidos da formação continuada, segundo o método ontopsicológico: um estudo com professores do Ensino Superior. 2013. 225f. Tese (Doutorado em Educação). Universidad del Mar, Viña del Mar, Cl, 2013. Revalidada pela UFSCar, 2015.

SPANHOL, C. I. D. Narrativa autobiográfica: a escolha otimal, mediada pela percepção organísmica. In: FUNDAÇÃO ANTONIO MENEGHETTI (Org.) Ontopsicologia: ciência interdisciplinar, Vol. III. Recanto Maestro, São João do Polêsine, RS: Fundação Antonio Meneghetti, 2017. 
Saber Humano, ISSN 2446-6298, V. 8, n. 13, p. 43-64, Jul./Dez. 2018.

VIDOR, A. Fenomenologia e Ontopsicologia: de Husserl a Meneghetti. Recanto Maestro: Ontopsicológica Editora Universitária, 2013. 